\title{
Carbon Dioxide-induced Changes in Color and Anthocyanin Synthesis of Stored Strawberry Fruit
}

\author{
Deirdre M. Holcroft ${ }^{1}$ and Adel A. Kader ${ }^{2}$ \\ Department of Pomology, University of California, One Shields Avenue, \\ Davis, CA 95616
}

Additional index words. Fragaria $\times$ ananassa, controlled-atmosphere storage, phenolics

\begin{abstract}
Anthocyanin concentrations increased in both external and internal tissues of 'Selva' strawberries (Fragaria $\times$ ananassa Duch.) stored in air at $5^{\circ} \mathrm{C}$ for 10 days, but the increase was lower in fruit stored in air enriched with 10 or $20 \mathrm{kPa} \mathrm{CO}_{2}$. Flesh red color was less intense in $\mathrm{CO}_{2}$ storage than in air storage. Activities of phenylalanine ammonia lyase (PAL) and UDP glucose : flavonoid glucosyltransferase (GT) decreased during storage, with decreases being greater in both external and internal tissues of strawberry fruit stored in air $+20 \mathrm{kPa} \mathrm{CO}$ than in those kept in air. Activities of both PAL and GT in external tissues of strawberries stored in air $+10 \mathrm{kPa} \mathrm{CO}$ were similar to those in fruit stored in air, while enzyme activities in internal tissues more closely resembled those from fruit stored in air $+20 \mathrm{kPa} \mathrm{CO}$. Phenolic compounds increased during storage but were not affected by the storage atmosphere. The $\mathrm{pH}$ increased and titratable acidity decreased during storage; these effects were enhanced in internal tissues by the $\mathrm{CO}_{2}$ treatments, and may in turn have influenced anthocyanin expression.
\end{abstract}

Anthocyanin synthesis continues in harvested fruit, particularly those stored in air, even at low storage temperatures. Increases have been observed in lowbush blueberry fruit (Vaccinium angustifolium Ait.) (Kalt and McDonald, 1996), where anthocyanin concentration increased by $18 \%$ after storage for 2 weeks at $1{ }^{\circ} \mathrm{C}$; in pomegranates (Punica granatum L.), where an increase of $71 \%$ was observed after 6 weeks of storage at $10^{\circ} \mathrm{C}$ (Holcroft et al., 1998); and in 'Blomidon' (Kalt et al., 1993) and 'Selva' strawberry fruit (19\% increase in whole fruit or $31 \%$ in external tissues after storage for $10 \mathrm{~d}$ at $5{ }^{\circ} \mathrm{C}$ ) (Gil et al., 1997). Treatment with $\mathrm{CO}_{2}$ inhibits this postharvest increase in anthocyanin concentration (Gil et al., 1997; Holcroft et al., 1998) by affecting anthocyanin biosynthesis, degradation, or both.

The biosynthesis of anthocyanins has been well studied (Holton and Cornish, 1995; Stafford, 1990). The first step of the phenylpropanoid pathway is the production of cinnamic acid from phenylalanine, produced via the shikimic acid pathway, by the action of phenylalanine ammonia lyase (PAL; EC 4.3.1.5). Cinnamic acid is converted into coumaric acid, which is modified to the CoA form. Three molecules of malonyl CoA combine with $\rho$-coumaroyl-CoA and form

Received for publication 17 May 1999. Accepted for publication 17 July 1999. The cost of publishing this paper was defrayed in part by the payment of page charges. Under postal regulations, this paper therefore must be hereby marked advertisement solely to indicate this fact.

${ }^{1}$ Current address: Dept. of Horticultural Science, Univ. of Stellenbosch, P. Bag X1, Matieland 7602, South Africa.

${ }^{2}$ To whom reprint requests should be addressed. naringenin chalcone, which is then converted into the flavanone, naringenin. The next step is the formation of dihydroflavonol, which is reduced toflavan-3,4-diol, or leucoanthocyanin, and then is converted to anthocyanidin. Finally, the glucose molecule is attached by the action of UDP glucose : flavonoid glucosyltransferase (GT; EC 2.4.1.91), resulting in the anthocyanin.

Our hypothesis is that elevated $\mathrm{CO}_{2}$ atmospheres during storage adversely affect anthocyanin biosynthesis in strawberry fruit, and that this effect is greater in the internal tissues of the fruit. To test this hypothesis we measured anthocyanin concentration and the specific activity of PAL and GT, two important enzymes involved in biosynthesis, in external and internal tissues of strawberry fruit. Other phenolic compounds were also analyzed in an attempt to understand whether the storage atmosphere could affect the partitioning of the precursors into various phenolic compounds. Since color expression and stability of anthocyanins is affected by $\mathrm{pH}$, we report $\mathrm{CO}_{2}-$ induced $\mathrm{pH}$ changes in fruit tissues.

\section{Materials and Methods}

Experimental setup. 'Selva' strawberries were harvested in Watsonville, Calif., and transported to the Univ. of California, Davis, in an air-conditioned vehicle and stored overnight at $5{ }^{\circ} \mathrm{C}$. Damaged berries were discarded and remaining berries were sorted for uniform size and color. Sixty fruit were placed in each $9.5-\mathrm{L}$ jar and three jars (replicates) were used per treatment. The jars were ventilated with a continuous flow of humidified air, air +10 or air $+20 \mathrm{kPaCO}_{2}$ at a flow rate of 170 $\mathrm{mL} \cdot \mathrm{min}^{-1}$ using needle valve flow boards. The gases were maintained within $10 \%$ of the required concentration (e.g., $10 \pm 1 \mathrm{kPa}$ ). The composition of the gases was checked regularly with a gas chromatograph equipped with a thermal conductivity detector (model 211; Carle Instruments, Anaheim, Calif.) or an infrared gas analyzer (model 2000R; Horiba Instruments, Irvine, Calif.).

Color. All the fruit were analyzed initially and after 5 and $10 \mathrm{~d}$ of storage at $5^{\circ} \mathrm{C}$. At each evaluation time 12 fruit per replicate were returned to the jars and held in air at $5{ }^{\circ} \mathrm{C}$ for a further $3 \mathrm{~d}$. External color was measured on opposite sides of the fruit using a Minolta chromameter (model CR-200; Minolta, Ramsey, N.J.), which provided CIE L*, a*, and $b^{*}$ values. These values were used to calculate chroma $\left(\mathrm{C}^{*}=\left[\mathrm{a}^{* 2}+\mathrm{b}^{* 2}\right]^{1 / 2}\right)$, which indicates the intensity or color saturation, and hue angle $\left(\mathrm{h}^{\circ}=\operatorname{arctangent}\left[\mathrm{b}^{*} / \mathrm{a}^{*}\right]\right)$ where $0^{\circ}=$ red-purple; $90^{\circ}=$ yellow; $180^{\circ}=$ bluish-green and $270^{\circ}=$ blue (McGuire, 1992). The fruit were sliced in half and internal flesh color was measured on both halves. External and internal color was also measured on the fruit that had been returned to air for $3 \mathrm{~d}$.

$p H, T A$, and TSS. Fruit halves were separated into external tissues (epidermis and about one-third of the cortex), internal (pith, bundle zone, and the remainder of the cortex), and the juice was analyzed separately for total soluble solids (TSS), $\mathrm{pH}$, and titratable acidity (TA). Soluble solids content was measured using an Abbe refractometer (model 10450; American Optical, Buffalo, N.Y.). A 4-g sample of juice was diluted with $20 \mathrm{~mL}$ of distilled water, and $\mathrm{pH}$ and TA were measured using an automatic titrator fitted with $\mathrm{pH}$ meter and an autoburette (PHM85 Precision, ABU80; Radiometer, Copenhagen, Denmark). TA was expressed as percentage of citric acid.

Anthocyanin extraction and analysis. Twenty halves per replicate were frozen in liquid $\mathrm{N}_{2}$ and kept at $-80^{\circ} \mathrm{C}$ until analyzed for anthocyanin and enzyme activities. The frozen tissue was removed from the freezer, allowed to thaw slightly, and separated into external and internal tissues as described previously. The separated tissue was immediately refrozen in liquid $\mathrm{N}_{2}$ before being ground in an Oster blender. Anthocyanins were extracted, separated, and quantified as described by Gil et al. (1997).

Enzyme extraction and analysis. The method of Lister et al. (1996) was used to extract and analyze PAL and GT, with the only difference being in the GT assay. UDP-glucose replaced UDP-galactose, and the product, quercetin 3-glucose, was quantified by the high-performance liquid chromatography (HPLC) method described in Holcroft et al. (1998).

Total and individual phenolics. Total soluble phenolic concentration was measured with a commercially available Folin \& Ciocalteau phenol reagent (Sigma Chemical Co., St. Louis) using $\rho$-coumaric acid as a standard (Singleton and Rossi, 1965). The extracts were prepared for HPLC analysis by dilution with $80 \%$ ethanol prior to analysis. All samples and standards were run in duplicate and absorbance was measured at $660 \mathrm{~nm}$. 
The samples prepared for anthocyanin analysis were analyzed for phenolics by HPLC using the method described in Gil et al. (1997).

Total protein. Total protein was extracted and measured from $1 \mathrm{~g}$ tissue initially and after $10 \mathrm{~d}$ of storage (Rothan et al., 1997).

Statistical analysis. Analysis of variance (ANOVA) of the main effects and LSD values with a significance level of 5\% were obtained using CoStat Statistical Software (version 5.01; CoHort Software, Minneapolis). Presented data points are the means of three replications \pm SE.

\section{Results and Discussion}

Skin and flesh color. Skin (external) color of strawberries became slightly darker ( $\mathrm{L}^{*}$ decreased) with time in storage but was not affected by storage atmosphere (Fig. 1A). The chroma values increased with time, and this increase was greater after $5 \mathrm{~d}$ storage in $\mathrm{CO}_{2}$ than in air. After $10 \mathrm{~d}$ at $5{ }^{\circ} \mathrm{C}$ chroma was not affected by storage atmospheres (Fig. 1C). However, the hue angle of berries held in air was lower than that of those held in either $\mathrm{CO}_{2}$ treatment (Fig. 1E).

The flesh (internal) color showed the most interesting changes in relation to the treatments, and $\mathrm{L}^{*}$, chroma, and hue were significantly affected $(P \leq 0.05)$ by $\mathrm{CO}_{2}$ treatments; $\mathrm{L}^{*}$ was lower (darker) (Fig. 1B) and the chroma was higher in air-stored fruit after $10 \mathrm{~d}$ (Fig. 1D). The chroma value of the fruit stored in air $+10 \mathrm{kPa} \mathrm{CO}_{2}$ was slightly higher than that of those stored in air $+20 \mathrm{kPaCO}_{2}$. These results confirm previous observations (Gil et al., 1997); $\mathrm{CO}_{2}$ treatments maintained a lighter color of the internal tissue of 'Selva' strawberry during storage, although the effect was not as marked in this experiment. The hue angle increased most, i.e., became more orange red, after storage in air $+10 \mathrm{kPa} \mathrm{CO}_{2}$ (43.8 after 10 d) (Fig. 1F). This agrees with our previous data where air $+10 \mathrm{kPaCO}_{2}$ also had a greater effect on hue angle (51.3 after $10 \mathrm{~d}$ ) (Gil et al., 1997).

The 12 fruit from each replicate that was transferred to air at $5{ }^{\circ} \mathrm{C}$ for a further $3 \mathrm{~d}$, after 5 and $10 \mathrm{~d}$ in air +10 or air $+20 \mathrm{kPa} \mathrm{CO}_{2}$, showed no increase in red color (data not shown).

Anthocyanin concentration. The total anthocyanin concentration in external tissue increased during storage in all treatments $(P \leq$ $0.05)$ (Fig. 2A). The increase $\left(146 \mu \mathrm{g} \cdot \mathrm{g}^{-1}\right)$ was greatest in air-stored fruit, reaching a maximum of $530 \mu \mathrm{g} \cdot \mathrm{g}^{-1}$ after $10 \mathrm{~d}$. Fruit stored in air did not differ significantly from those stored in $10 \mathrm{kPa} \mathrm{CO}$-enriched air. The increase in anthocyanin concentration in fruit stored in air + $20 \mathrm{kPa} \mathrm{CO}$ was $47 \mu \mathrm{g} \cdot \mathrm{g}^{-1}$ over the 10 -d storage period. The anthocyanin concentration in fruit stored in air $+20 \mathrm{kPa} \mathrm{CO}_{2}$ was significantly $(P \leq 0.05)$ lower than in fruit in the other two treatments after $10 \mathrm{~d}$.

Initially, the anthocyanin concentration in

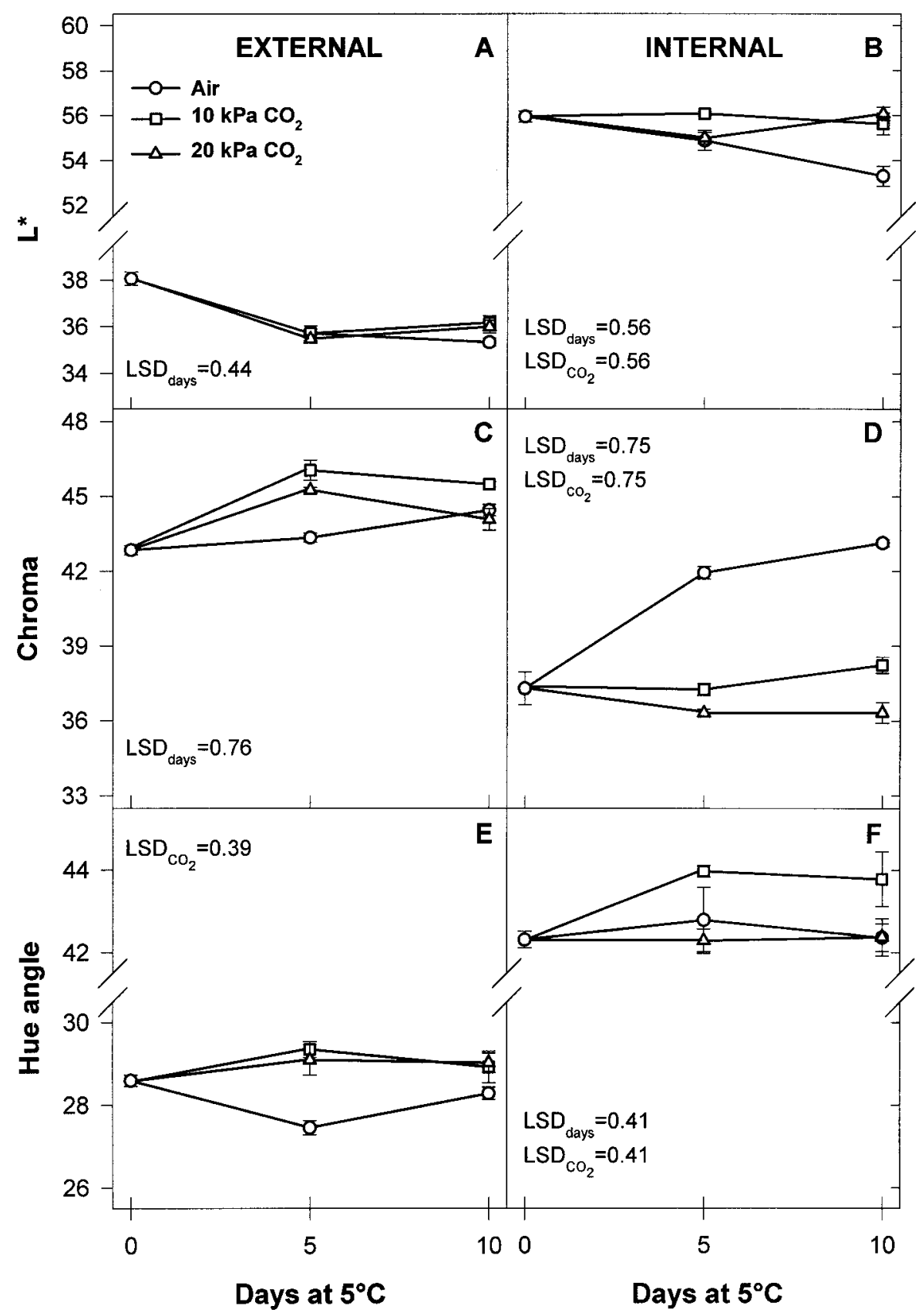

Fig. 1. External (skin) and internal (flesh) color, measured as $\mathrm{L}^{*}$ or lightness $(\mathbf{A}, \mathbf{B})$, chroma $(\mathbf{C}, \mathbf{D})$ and hue angle $(\mathbf{E}, \mathbf{F})$, of 'Selva' strawberries stored at $5{ }^{\circ} \mathrm{C}$ for 5 or $10 \mathrm{~d}$ in air or $\mathrm{CO}_{2}$-enriched atmospheres.

the internal fruit tissues was much lower than in the external tissues (118 vs. $384 \mu \mathrm{g} \cdot \mathrm{g}^{-1}$, respectively). An increase of $38 \mu \mathrm{g} \cdot \mathrm{g}^{-1}$ of anthocyanin was measured in internal tissue of air-stored fruit over the 10-d period, while no increase occurred in fruit stored in air +20 $\mathrm{kPa} \mathrm{CO}_{2}$ (Fig. 2B). The major difference between external and internal tissues was in the response of fruit stored in air $+10 \mathrm{kPa} \mathrm{CO}_{2}$; anthocyanin concentration in the external tissue was similar to that of air-stored fruit, while that in the internal tissue was similar to that of fruit stored in air $+20 \mathrm{kPa} \mathrm{CO}_{2}$.

The anthocyanin concentrations appear higher than our previously reported concentrations (Gil et al., 1997), but in the first instance we used a standard of cyanidin 3glucoside (Cy 3-G) to quantify the anthocyanin concentration and in this work we used pelargonidin 3-glucoside (Pg 3-G). A comparison of peak areas from the chromatograms indicates that the concentrations were similar in the two experiments; Pg 3-G was the most abundant pigment in strawberry fruit, and accounted for $\approx 88 \%$ of the anthocyanin in external tissues and $96 \%$ in internal tissues, while pelargonidin 3-rutinoside (Pg 3-R) accounted for $4 \%$ of the total anthocyanin in both exter- 


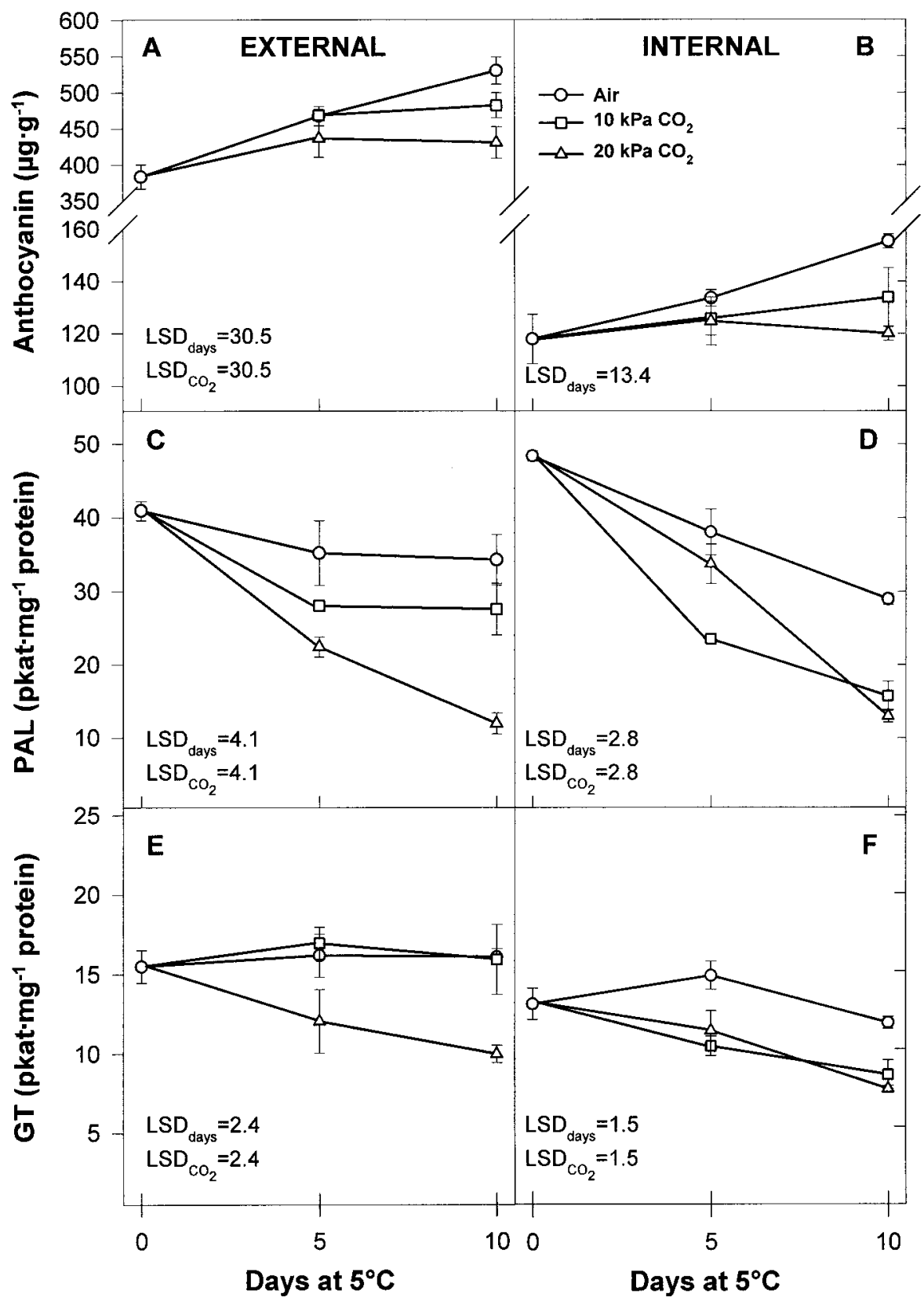

Fig. 2. Total anthocyanin concentration $\left(\mu \mathrm{g} \cdot \mathrm{g}^{-1}\right)(\mathbf{A}, \mathbf{B})$ and activities of PAL $(\mathbf{C}, \mathbf{D})$ and GT $(\mathbf{E}, \mathbf{F})$ ( $\rho$ kat $\cdot \mathrm{mg}^{-1}$ protein) from the external and internal tissue of 'Selva' strawberries stored at $5{ }^{\circ} \mathrm{C}$ for 5 or $10 \mathrm{~d}$ in air or $\mathrm{CO}_{2}$-enriched atmospheres.

nal and internal tissues. Cyanidin 3-glucoside was present in external tissues $(8 \%)$ but completely lacking in the internal tissues. These differential concentrations help explain the large differences in hue angle between the skin and the flesh of the strawberry, since Pg derivatives are scarlet red while Cy derivatives tend to be crimson red. Changes in the relative percentage of each as a result of storage treatment were small, except in external tissues of fruit stored for $10 \mathrm{~d}$ in air $+20 \mathrm{kPaCO}_{2}$, where the concentration of $\mathrm{Cy} 3-\mathrm{G}$ was lower and the cyanin concentration was low, PAL activity was also low (Fig. 2). A similar relationship was seen between GT activity and anthocyanin concentration. Activity of GT remained fairly constant in air-stored fruit but decreased in fruit stored in air $+20 \mathrm{kPa} \mathrm{CO}_{2}$, whereas GT activity in fruit stored in air $+10 \mathrm{kPa} \mathrm{CO}_{2}$ was similar to that in the air-stored fruit (Fig. 2E).

The activities of PAL and GT in the internal tissues were affected by both storage time and atmosphere $(P \leq 0.01)$ (Fig. 2$)$. The activities of both enzymes were always higher in airstored fruit than in fruit stored in elevated $\mathrm{CO}_{2}$ atmospheres. Activity of PAL in fruit stored in air $+20 \mathrm{kPaCO}_{2}$ for $10 \mathrm{~d}$ was $44.9 \%$ of that of the air-stored control, and GT activity was significantly $(P \leq 0.05)$ lower after $10 \mathrm{~d}$ of storage in the $\mathrm{CO}_{2}$-stored fruit $\left(7.4 \rho \mathrm{kat} \cdot \mathrm{mg}^{-1}\right.$ protein, in air $+20 \mathrm{kPa} \mathrm{CO}_{2}$ vs. 11.7 pkat $\cdot \mathrm{mg}^{-1}$ protein in air) (Fig. 2F).

In 'Selva' strawberry fruit both PAL and GT activities were affected by $\mathrm{CO}_{2}$-enriched atmospheres. This relationship differed from pomegranates, where the anthocyanin concentration was correlated to PAL activity, but GT activity was unaffected by storage atmosphere (Holcroft et al., 1998). Increases in the activities of PAL and GT have been positively correlated with anthocyanin production in several fruits, including strawberry (Cheng and Breen, 1991; Given et al., 1988). Given et al. (1988) found that activity of GT was about one-third of that of PAL, and we noted a similar difference. However, the activities of both enzymes were lower in our experiment, probably because collection of data was restricted to a 10-d postharvest period, whereas Given et al. (1988) measured activity during fruit development.

Phenolics. The total soluble phenolic concentration, measured as $\rho$-coumaric acid equivalents by Folin-Ciocalteau assay, or as the sum of the individually identified phenolic compounds, followed the same trends in both external and internal tissues (Table 1). The content of phenolic compounds increased with time $(P \leq 0.05)$ in storage but was unaffected by storage atmosphere. It was significantly higher in external tissues than in internal tissues, with ellagic acid and flavonols (quercetin and kaempferol derivatives) present only in the external tissues, while catechin and $\rho$ coumaroyl glucose occurred throughout the fruit (Table 1). Generally, the concentrations of individual phenolics increased during storage, particularly in air. An increase in concentration after $5 \mathrm{~d}$ of storage in air $+20 \mathrm{kPa} \mathrm{CO}_{2}$ was observed, although by $10 \mathrm{~d}$ the concentrations were usually lower than in the air control, indicating that degradation of phenolic compounds may increase after prolonged storage in elevated $\mathrm{CO}_{2}$ atmospheres.

Differences in concentrations of phenolic compounds between the two methods may reflect the fact that HPLC specifically measures simple phenolics, whereas the Folin- 


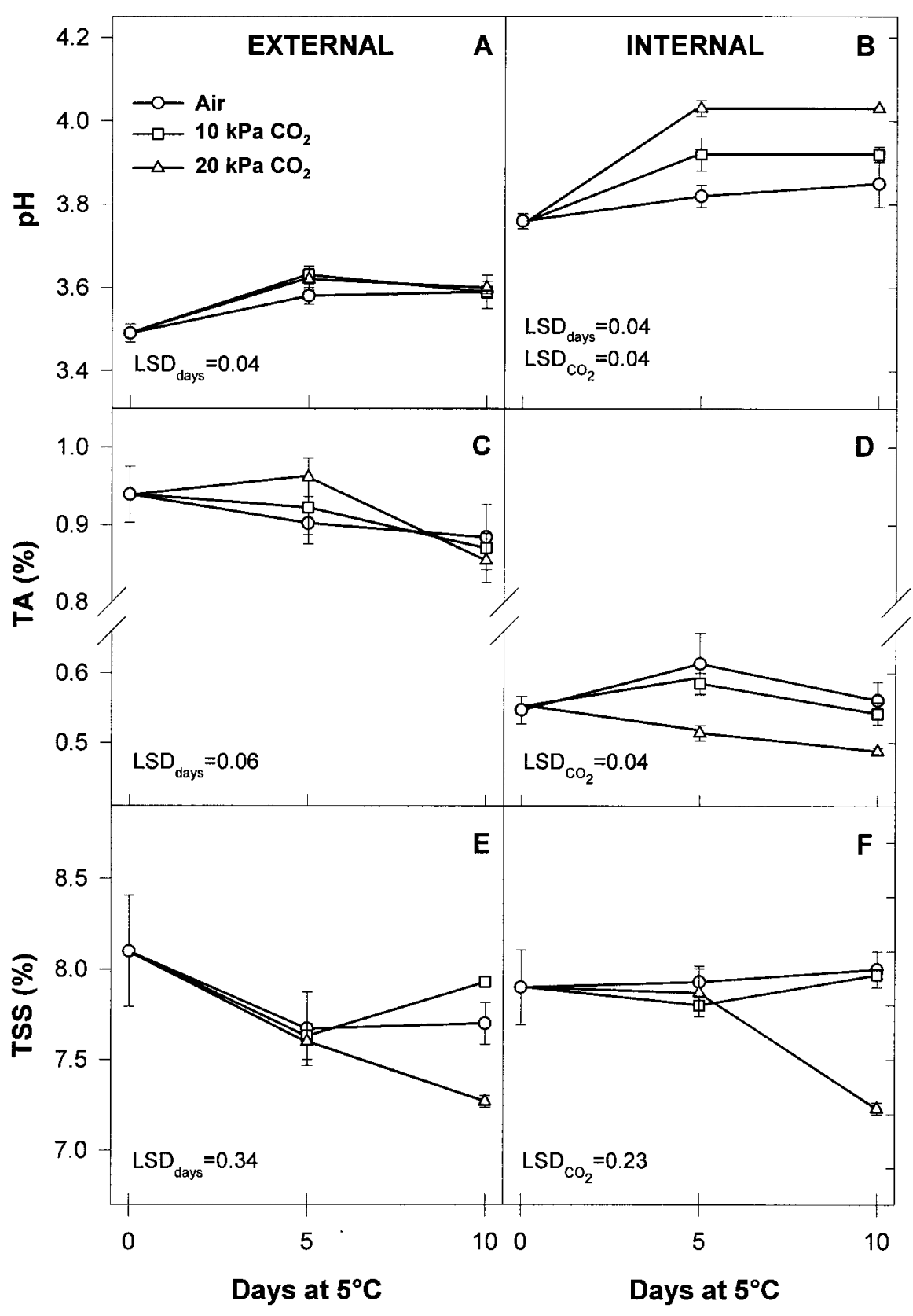

Fig. 3. pH (A, B), titratable acidity (TA) (C, D) and total soluble solids content (TSS) (E, F) of external and internal tissue of 'Selva' strawberries stored at $5{ }^{\circ} \mathrm{C}$ for 5 or $10 \mathrm{~d}$ in air or $\mathrm{CO}_{2}$-enriched atmospheres.

Ciocalteau assay is a nonspecific method that measures simple phenolics, polyphenols, flavonoids, tannins, and some readily oxidized substances such as ascorbic acid (Singleton and Rossi, 1965).

Total protein. Extractable protein was lower in internal than in external tissue (2.7 vs. 3.2 $\mu \mathrm{g} \cdot \mathrm{g}^{-1}$, respectively) and increased by 0.4 $\mu \mathrm{g} \cdot \mathrm{g}^{-1}$ in both tissues $(P \leq 0.05)$ after $10 \mathrm{~d}$ at $5^{\circ} \mathrm{C}$. However, this increase was not affected $p H, T A$, and TSS. Initially, the $\mathrm{pH}$ of the internal tissue was slightly higher than that of external tissue (3.76 vs. 3.49, respectively) (Fig. $3 \mathrm{~A}$ and B). External pH increased by only 0.1 unit during storage and the differences between the storage treatments were negligible after $10 \mathrm{~d}$ (Fig. 3A). During $10 \mathrm{~d}$ of storage the $\mathrm{pH}$ of the internal tissues increased by $0.27 \mathrm{pH}$ unit in air $+20 \mathrm{kPa} \mathrm{CO}$, vs. only 0.09 unit in air (Fig. 3B). The TA was considerably lower in internal (Fig. 3C) than external tissues $(0.55 \%$ vs. $0.94 \%$, respectively). In both tissues, TA decreased with time in storage. TA of the internal tissues of fruit stored for $10 \mathrm{~d}$ in air $+20 \mathrm{kPaCO}_{2}$ was lower than that of fruit stored in air $(0.49 \%$ vs. $0.56 \%$, respectively) (Fig. 3D).

Anthocyanin analysis by HPLC was conducted at a low $\mathrm{pH}$ to enhance the stability of the pigments, and this favors conversion to the red flavylium form. Consequently, the correlation between anthocyanin concentration and visual color may be poor. This overestimation of the red form of anthocyanin was seen in pomegranates (Holcroft et al., 1998), where anthocyanin values measured by HPLC analysis correlated poorly with those calculated from absorbance $(510 \mathrm{~nm})$ measured in a buffered dilution $(\mathrm{pH} 3.5)$.

The color reversal data show no recovery of internal fruit color in strawberry after $3 \mathrm{~d}$ in air, indicating that any normalization of $\mathrm{pH}$ caused by return to air did not affect color expression. Either there was no major effect of $\mathrm{pH}$ on color, or degradation of the chalcone had already occurred.

TSS did not differ significantly between internal and external tissues. Storage atmospheres did not affect TSS until after $10 \mathrm{~d}$ of exposure, when TSS was lower in both external and internal tissues of fruit stored in air + $20 \mathrm{kPa} \mathrm{CO}$ (Fig. $3 \mathrm{E}$ and F). Lewis et al. (1995) found that the absorbance of anthocyanins increased when glucose, sucrose or maltose (all $50 \% \mathrm{w} / \mathrm{v}$ ) were added, although the absorbance maxima remained unchanged. This hyperchromic shift may be caused by a reduction in water activity by high sugar concentrations, causing the equilibrium to favor the flavylium ion. This effect was greater at $\mathrm{pH} 4$ than at $\mathrm{pH}$ 2. The lower TSS values in the air $+20 \mathrm{kPaCO}$ treatment, in combination with higher $\mathrm{pH}$, may also have affected anthocyanin stability.

Despite the benefits of $\mathrm{CO}_{2}$-enriched atmospheres in controlling postharvest decay of strawberry fruit, these atmospheres adversely affected fruit color, anthocyanin concentration, and the activities of at least two enzymes in the anthocyanin biosynthetic pathway. The effects were more obvious in the internal tissues. 
Table 1. Mean concentrations of phenolic compounds $\left(\mu \mathrm{g} \cdot \mathrm{g}^{-1}\right)$ in external and internal tissues of 'Selva' strawberries stored at $5{ }^{\circ} \mathrm{C}$ for 5 or $10 \mathrm{~d}$ in air or air enriched with $\mathrm{CO}_{2}$.

\begin{tabular}{|c|c|c|c|c|c|c|c|c|}
\hline $\begin{array}{l}\text { Days } \\
\text { in storage } \\
\end{array}$ & $\mathrm{CO}_{2}(\mathrm{kPa})$ & Catechin & $\begin{array}{l}\rho \text {-Coumaroyl } \\
\text { glucose }\end{array}$ & $\begin{array}{l}\text { Ellagic } \\
\text { acid }\end{array}$ & $\begin{array}{c}\text { Quercetin } \\
\text { derivatives }\end{array}$ & $\begin{array}{c}\text { Kaempferol } \\
\text { derivatives }\end{array}$ & $\begin{array}{l}\text { Total } \\
\text { (sum) }\end{array}$ & $\begin{array}{c}\text { Total } \\
\text { ( } \rho \text {-coumaric } \\
\text { acid equiv.) }\end{array}$ \\
\hline \multicolumn{9}{|c|}{ External tissue } \\
\hline 0 & --- & 118 & 8 & 24 & 47 & 24 & 221 & 1705 \\
\hline \multirow[t]{4}{*}{5} & 0 & 160 & 13 & 22 & 54 & 30 & 279 & 1924 \\
\hline & 10 & 171 & 10 & 22 & 55 & 29 & 287 & 1986 \\
\hline & 20 & 190 & 11 & 20 & 52 & 27 & 300 & 2011 \\
\hline & Mean & 174 & 11 & 21 & 54 & 29 & 289 & 1974 \\
\hline \multirow[t]{4}{*}{10} & 0 & 190 & 16 & 23 & 67 & 31 & 327 & 2040 \\
\hline & 10 & 214 & 11 & 21 & 60 & 30 & 336 & 1957 \\
\hline & 20 & 184 & 10 & 20 & 51 & 29 & 294 & 1869 \\
\hline & Mean & 196 & 12 & 21 & 59 & 30 & 318 & 1955 \\
\hline $\operatorname{LSD}_{\text {days }}(5 \%)$ & & 21.5 & 1.8 & NS & 9.9 & 2.3 & 26.3 & 68 \\
\hline \multicolumn{9}{|c|}{ Internal tissue } \\
\hline 0 & --- & 122 & 16 & $--^{z}$ & --- & --- & 138 & 966 \\
\hline \multirow[t]{4}{*}{5} & 0 & 154 & 21 & --- & --- & --- & 175 & 1009 \\
\hline & 10 & 151 & 18 & --- & --- & --- & 169 & 1054 \\
\hline & 20 & 167 & 19 & --- & --- & --- & 186 & 1222 \\
\hline & Mean & 157 & 19 & --- & --- & --- & 176 & 1062 \\
\hline \multirow[t]{4}{*}{10} & 0 & 167 & 23 & --- & --- & --- & 190 & 1121 \\
\hline & 10 & 163 & 17 & --- & --- & --- & 180 & 1093 \\
\hline & 20 & 124 & 17 & --- & --- & --- & 141 & 984 \\
\hline & Mean & 151 & 19 & --- & --- & --- & 170 & 1066 \\
\hline $\operatorname{LSD}_{\text {days }}(5 \%)$ & & 16.1 & 1.7 & & & & 15.4 & NS \\
\hline
\end{tabular}

${ }^{\mathrm{z} N o t}$ detected.

\section{Literature Cited}

Cheng, G.W. and P.J. Breen. 1991. Activity of phenylalanine ammonia-lyase (PAL) and concentrations of anthocyanins and phenolics in developing strawberry fruit. J. Amer. Soc. Hort. Sci. 116:865-869.

Gil, M.I., D.M. Holcroft, and A.A. Kader. 1997. Changes in strawberry anthocyanins and other polyphenols in response to carbon dioxide treatments. J. Agr. Food Chem. 45:1662-1667.

Given, N.K., M.A. Venis, and D. Grierson. 1988. Phenylalanine ammonia-lyase activity and anthocyanin synthesis in ripening strawberry fruit. J. Plant Physiol. 133:25-30.

Holcroft, D.M., M.I. Gil, and A.A. Kader. 1998. Effect of carbon dioxide on anthocyanins, phenylalanine ammonia lyase and glucosyltrans- ferase in the arils of stored pomegranates. J. Amer. Soc. Hort. Sci. 123:136-140.

Holton, T.A. and E.C. Cornish. 1995. Genetics and biochemistry of anthocyanin biosynthesis. Plant Cell 7:1071-1083.

Kalt, W. and J.E. McDonald. 1996. Chemical composition of lowbush blueberry cultivars. J. Amer. Soc. Hort. Sci. 121:142-146.

Kalt, W., R.K. Prange, and P.D. Lidster. 1993. Postharvest color development of strawberries: Influence of maturity, temperature and light. Can. J. Plant Sci. 73:541-548.

Lewis, C.E., J.R.L. Walker, and J.E. Lancaster. 1995. Effect of polysaccharides on the colour of anthocyanins. Food Chem. 54:315-319.

Lister, C.E., J.E. Lancaster, and J.R.L. Walker. 1996. Developmental changes in enzymes of flavonoid biosynthesis in the skins of red and green apple cultivars. J. Sci. Food Agr. 71:313320 .

McGuire, R.G. 1992. Reporting of objective color measurements. HortScience 27:1254-1255.

Rothan, C., S. Duret, C. Chevalier, and P. Raymond. 1997. Suppression of ripening associated gene expression in tomato fruits subjected to a high $\mathrm{CO}_{2}$ concentration. Plant Physiol. 114:255-263.

Singleton, V.L. and J.A. Rossi. 1965. Colorimetry of total phenolics with phosphomolybdic-phosphotungstic acid reagents. Amer. J. Enol. Viticult. 16:144-157.

Stafford, H.A. 1990. Flavonoid metabolism. CRC Press, Boca Raton, Fla.

Zucker, M. 1965. Induction of phenylalanine deaminase by light and its relation to chlorogenic acid synthesis in potato tuber tissue. Plant Physiol. 40:779-784. 